\title{
PENGARUH SUHU PRODUKSI TERHADAP AKTIVITAS EKSTRAK KASAR BAKTERIOSIN DARI BERBAGAI GALUR Lactobacillus sp. DALAM MENGHAMBAT Escherichia coli DAN Staphylococcus aureus
}

\section{EFFECT OF TEMPERATURE ON INHIBITORY ACTIVITY OF CRUDE EXTRACT BACTERIOCIN PRODUCED BY DIFFERENT STRAINS OF Lactobacillus sp. ON SURVIVAL OF Escherichia coli AND Staphylococcus aureus}

\author{
Abubakar $^{1 *}$ dan Muhammad Arpah ${ }^{2}$ \\ ${ }^{1}$ Balai Besar Penelitian dan Pengembangan Pascapanen Pertanian, Bogor, 16114 \\ ${ }^{2}$ Fakultas Teknologi Pertanian, Institut Pertanian Bogor, Bogor, 16680
}

Submitted: 6 May 2015, Accepted: 16 September 2015

\section{INTISARI}

\begin{abstract}
Sistem biopreservasi pangan mulai menarik perhatian di kalangan industri dan konsumen. Penggunaan bakteri asam laktat dan/atau senyawa bakteriosin yang dihasilkan oleh bakteri asam laktat sudah dinyatakan aman (generally recognize as safe). Penelitian ini dilakukan untuk membandingkan aktivitas penghambatan ekstrak kasar bakteriosin yang dihasilkan oleh Lactobacillus sp. galur SCG 1211, SCG 1221, dan SCG 1223; serta untuk mengetahui pengaruh suhu pemanasan pada temperatur $80^{\circ} \mathrm{C}$ dan $100^{\circ} \mathrm{C}$. Produksi bakteriosin pada penelitian ini menerapkan prinsip adsorbsi-desorbsi. Aktivitas penghambatan ditunjukkan dengan adanya zona bening di sekeliling sumur agar. Hasil penelitian menunjukkan suhu pemanasan tidak berpengaruh nyata terhadap aktivitas penghambatan $(P>0,05)$. Aktivitas hambat tertinggi ditunjukkan oleh ekstrak kasar bakteriosin dari Lactobacillus sp. galur SCG 1211 , yaitu sebesar 840,90 AU/ml terhadap Escherichia coli dan 979,12 AU/ml terhadap Staphylococcus aureus.
\end{abstract}

(Kata kunci: Adsorbsi-desorbsi, Aktivitas penghambatan, Bakteriosin, Biopreservasi, Lactobacillus sp.)

\section{ABSTRACT}

The biopreservation systems are recently of food industries and consumers attract. Lactic acid bacteria and/or their isolated bacteriocins are considered as generally recognize as safe (GRAS). It is useful to control the frequent development of pathogens and spoilage microorganisms in foods. This study was aimed to compare the activity of crude extract bacteriocins from Lactobacillus sp. strain SCG 1211, SCG 1221, and SCG 1223, which suppressed the growth of Escherichia coli and Staphylococcus aureus; and to compare the effect of heating temperature at $80^{\circ} \mathrm{C}$ and $100^{\circ} \mathrm{C}$. Adsorbtion-desorbtion method was applied in the production step. The inhibitory activities of the bacteriocins were indicated by the presence of a transparent zone surrounding the agar wells. The result showed that inhibitory activities of crude extract bacteriocin were not affected by heating temperature $(P>0.05)$. The highest activity was shown by crude extract bacteriocin from Lactobacillus sp. strain SCG 1211, with the activity at $840.90 \mathrm{AU} / \mathrm{ml}$ towards Escherichia coli and $979.12 \mathrm{AU} / \mathrm{ml}$ towards Staphylococcus aureus.

(Key words: Adsorbtion-desorbtion, Bacteriocin, Biopreservative, Inhibitory activity, Lactobacillus sp.)

\footnotetext{
${ }^{*}$ Korespondensi (corresponding author):

Telp.+62 85772599704

E-mail: abu.028@gmail.com
} 


\section{Pendahuluan}

Salah satu masalah yang menjadi perhatian di industri pangan adalah kontaminasi pangan oleh patogen, khususnya pada jenis pangan perishable (mudah membusuk) seperti daging dan karkas ayam. Penggunaan agensia pengawet biasanya diaplikasikan untuk mencegah terjadinya kontaminasi oleh mikrobia patogen maupun mikrobia pembusuk, sehingga dapat memperpanjang umur simpan produk pangan. Penggunaan pengawet kimia pada produk pangan masih diragukan keamanannya karena meninggalkan residu kimia dalam tubuh manusia. Penggunaan pengawet kimia pada produk pangan mulai digantikan dengan biopreservatif. Penggunaan mikrobia nonpatogen dan/atau senyawa metabolitnya untuk meningkatkan keamanan mikrobiologis produk pangan serta untuk memperpanjang umur simpan produk pangan didefinisikan sebagai biopreservasi (De Martinis et al., 2001).

Bakteriosin merupakan salah satu agen biopreservasi, berupa protein atau peptida antimikrobial yang dihasilkan oleh bakteri, disintesis secara ribosomal, dan dapat membunuh mikrobia yang memiliki kedekatan secara filogenik dengan mikrobia produsernya (Klaenhammer, 1993).

Bakteriosin dapat dihasilkan dari berbagai jenis bakteri, baik dari kelompok gram negatif maupun gram positif. Bakteriosin yang diproduksi oleh bakteri gram negatif memiliki aktivitas hambat relatif sempit, sedangkan bakteriosin yang diproduksi bakteri gram positif memiliki aktivitas hambat relatif lebih luas dalam menghambat bakteri gram positif maupun gram negatif (De Vuyst dan Leroy, 2007). Bakteri gram positif yang digunakan sebagai produsen bakteriosin umumnya berasal dari kelompok bakteri asam laktat (BAL). Bakteriosin yang dihasilkan BAL dapat mengalami degradasi oleh enzim proteolitik dalam pencernaan manusia, sehingga tidak membahayakan bagi kesehatan manusia. Oleh karena itu, bakteriosin berpotensi untuk menggantikan peran agensia pengawet kimia dalam industri pangan.

Bakteriosin umumnya menunjukkan kestabilan aktivitas pada pengaruh suhu dan pH (Nurhasanah, 2004), namun sensitivitasnya terhadap suhu maupun $\mathrm{pH}$ akan berbeda setiap jenisnya. Pada kondisi asam maupun basa, bakteriosin tetap menunjukkan aktivitas yang stabil. Bakteriosin juga menunjukkan aktivitas yang stabil setelah diberikan perlakuan pada suhu $-20^{\circ} \mathrm{C}$ sampai $100^{\circ} \mathrm{C}$. Oleh karena itu, bakteriosin dapat digunakan sebagai agensia pengawet pada industri pangan yang umumnya melibatkan pengaturan suhu dan $\mathrm{pH}$ (Nurhasanah, 2004).

Proses produksi bakteriosin dipengaruhi oleh beberapa faktor: jenis bakteri produser, kondisi fermentasi, $\mathrm{pH}$ produksi, suhu produksi, keberadaan enzim proteolitik, dan komposisi nutrisi media pertumbuhan (Todorov dan Dicks, 2004). Produksi bakteriosin biasanya dilakukan pada media sintetik seperti MRSB (de Man, Rogosa, dan Sharpe Broth), TGE (Tryptone Glucose Extract Yeast), atau media sintetik lainnya. Namun, pada umumnya media sintetik yang digunakan dalam produksi bakteriosin yang dihasilkan BAL adalah media MRSB. Penelitian ini bertujuan untuk mengetahui pengaruh suhu pemanasan yang digunakan dalam produksi bakteriosin terhadap aktivitas bakteriosin, serta untuk membandingkan kemampuan aktivitas bakteriosin dari beberapa galur bakteri asam laktat yang digunakan dalam menghambat bakteri Escherichia coli (E. coli) dan Staphylococcus aureus (S. aureus).

\section{Materi dan Metode}

Mikrobia yang digunakan sebagai kultur produser bakteriosin adalah kultur cair Lactobacillus sp. galur SCG 1211, SCG 1221 dan SCG 1223 koleksi Balai Besar Penelitian dan Pengembangan Pascapanen Pertanian Bogor, hasil peremajaan dari isolat yang diisolasi oleh Balai Besar Penelitian dan Pengembangan Bioteknologi dan Sumber Daya Genetika Bogor. Ketiga kultur merupakan hasil isolasi dari susu murni. Mikrobia yang digunakan sebagai bakteri indikator dalam pengujian aktivitas hambat ekstrak kasar bakteriosin adalah $S$. aureus dan E. coli. Media pertumbuhan bakteri yang digunakan adalah Nutrient Broth (Criterion), de Man, Rogosa, and Sharpe (MRS) Broth (Oxoid), MRS Agar (Oxoid), Plate Count Agar (Oxoid), dan ekstrak khamir (Bacto ${ }^{\mathrm{TM}}$ ). Bahan kimia yang digunakan adalah $\mathrm{NaCl}$ (Merck), $\mathrm{NaOH}$ (Merck), $\mathrm{HCl}$ (Merck), alkohol 76\%, buffer fosfat $\mathrm{pH} 7,00$ dan $\mathrm{pH} 4,00$. 
Penelitian ini terdiri dari tiga tahap yaitu peremajaan dan penghitungan jumlah koloni masing-masing kultur, produksi bakteriosin dan pengujian aktivitas hambat ekstrak kasar bakteriosin terhadap bakteri indikator.

\section{Peremajaan kultur}

Sebanyak $1 \mathrm{ml}$ kultur BAL diinokulasi ke dalam $9 \mathrm{ml}$ media MRSB dengan pengkayaan 3\% ekstrak khamir. Inkubasi selama $24-48$ jam pada suhu $37^{\circ} \mathrm{C}$. Hal serupa juga dilakukan pada kultur $E$. coli dan $S$. aureus. Sebanyak $1 \mathrm{ml}$ kultur diinokulasi ke dalam $9 \mathrm{ml}$ media NB, kemudian diinkubasi pada suhu $37^{\circ} \mathrm{C}$ selama 24 jam (FDA, 2001).

\section{Penghitungan populasi kultur dengan metode aerobic plate count}

Analisis populasi kultur menggunakan metode FDA (2001). Sebanyak $1 \mathrm{ml}$ hasil peremajaan kultur diencerkan dalam $9 \mathrm{ml}$ larutan garam fisiologis. Pengenceran dilakukan hingga tingkat pengenceran kesembilan untuk kultur BAL, sedangkan kultur bakteri indikator diencerkan hingga tingkat pengenceran keempat belas. Sebanyak $1 \mathrm{ml}$ dari masing-masing pengenceran ditumbuhkan pada 20-25 ml media agar dengan cawan tuang. Media agar yang digunakan untuk pengenceran kultur BAL adalah MRSA, sedangkan bakteri indikator menggunakan media PCA. Setelah membeku, cawan diinkubasi dengan posisi terbalik pada suhu $37^{\circ} \mathrm{C}$ selama 24 jam untuk bakteri indikator dan selama 24-48 jam untuk $\mathrm{BAL}$, kemudian dilakukan penghitungan koloni pada cawan yang memiliki jumlah 25250 koloni dan dijumlahkan dengan persamaan sebagai berikut:

$$
\mathrm{N}=\frac{\sum \text { Koloni }}{(1 \times \mathrm{n} 1)+(0,1 \times \mathrm{n} 2)} \times \mathrm{d}
$$

Keterangan:

$\mathrm{N}=$ jumlah koloni per $\mathrm{ml}$

$\mathrm{n} 1$ = jumlah cawan terhitung pada pengenceran pertama

$\mathrm{n} 2$ = jumlah cawan terhitung pada pengenceran kedua

$\mathrm{d}$ = pengenceran pertama yang terhitung.

\section{Produksi bakteriosin}

Analisis produksi bakteriosin menggunakan metode Usmiati dan Rahayu (2011). Sebanyak $1 \mathrm{ml}$ hasil peremajaan masingmasing BAL diinokulasi dalam $9 \mathrm{ml}$ MRSB, diinkubasi selama 24 jam pada suhu $37^{\circ} \mathrm{C}$, kemudian sebanyak $4 \mathrm{ml}$ kultur BAL berumur 24 jam diinokulasikan pada $36 \mathrm{ml}$ media kerja MRSB, diinkubasi pada suhu $37^{\circ} \mathrm{C}$ selama 9 jam dengan shaker inkubator. Setelah itu, $\mathrm{pH}$ diatur hingga 6,0 dengan menggunakan $\mathrm{NaOH} 1 \mathrm{~N}$, dipanaskan pada suhu $80^{\circ} \mathrm{C}$ dan $100^{\circ} \mathrm{C}$ selama 15 menit, diinkubasi pada suhu $4^{\circ} \mathrm{C}$ selama 24 jam, selanjutnya disentrifugasi dengan kecepatan $10.000 \mathrm{rpm}$ selama 15 menit pada suhu $4^{\circ} \mathrm{C}$. $\mathrm{pH}$ diatur kembali menjadi 4,0 dengan menggunakan $\mathrm{HCl} 1 \mathrm{~N}$, selanjutnya diinkubasi kembali pada suhu $4^{\circ} \mathrm{C}$ selama 24 jam, disentrifugasi dengan kecepatan $10.000 \mathrm{rpm}$ selama 15 menit pada suhu $4^{\circ} \mathrm{C}$. Supernatan yang dihasilkan selanjutnya disaring menggunakan millipore $0,20 \mu \mathrm{m}$ dan didapatkan ekstrak kasar bakteriosin.

\section{Pengujian aktivitas bakteriosin metode difusi sumur agar}

Uji aktivitas bakteriosin sesuai dengan metode difusi sumur agar (modifikasi Delgado et al., 2005). Bakteri indikator berumur 24 jam diencerkan dalam larutan garam fisiologis hingga berjumlah $10^{9} \mathrm{cfu} / \mathrm{ml}$. Sebanyak $1 \mathrm{ml}$ suspensi bakteri indikator yang diperoleh diinokulasikan ke dalam 15-20 ml PCA dengan cawan tuang. Setelah agar memadat, dibuat sumur berdiameter $6 \mathrm{~mm}$ dengan menggunakan alat sumuran (cokr borer). Sampel ekstrak bakteriosin yang akan diuji diambil sebanyak $50 \mu \mathrm{l}$ dan dimasukkan ke dalam sumur pada media uji dan dibiarkan hingga sampel berdifusi, kemudian cawan agar diinkubasi pada suhu $37^{\circ} \mathrm{C}$ selama 24 jam. Aktivitas bakteriosin akan terlihat dengan munculnya zona bening di sekitar sumur. Unit aktivitas bakteriosin dapat didefinisikan dalam Arbitrary Unit per $\mathrm{ml}(\mathrm{AU} / \mathrm{ml})$. $1 \mathrm{AU}$ per $\mathrm{ml}$ merupakan luas daerah hambatan per satuan volume sampel bakteriosin yang diuji (Tagg dan McGiven, 1971). Aktivitas bakteriosin dapat dihitung dengan menggunakan persamaan berikut:

$$
\text { Aktivitas bakteriosin }(\mathrm{AU} / \mathrm{ml})=\frac{\mathrm{Lz}-\mathrm{Ls}}{\mathrm{V}}
$$

\footnotetext{
Keterangan:

$\mathrm{Lz}=$ luas zona bening $\left(\mathrm{mm}^{2}\right)$

$\mathrm{V}=$ volume sampel bakteriosin $(\mathrm{ml})$

$\mathrm{Ls}=$ luas sumur $\left(\mathrm{mm}^{2}\right)$.
}

Selanjutnya, data dilakukan analisis ragam (rancangan blok acak lengkap) dengan faktor I galur kultur produsen, masing-masing 
dengan 3 ulangan (U1, U2, U3) dan faktor II suhu produksi, masing-masing suhu dengan 2 ulangan (U1 dan U2). Analisis ragam ini dilakukan untuk mengetahui ada atau tidaknya pengaruh dari kedua faktor tersebut terhadap aktivitas penghambatan ekstrak bakteriosin yang dihasilkan.

\section{Hasil dan Pembahasan}

\section{Penghitungan total populasi kultur}

Jumlah populasi kultur BAL disajikan pada Tabel 1 dan jumlah populasi bakteri indikator dapat dilihat pada Tabel 2. Dari Tabel 1 diketahui bahwa kultur Lactobacillus sp. galur SCG 1211 yang digunakan memiliki jumlah koloni terbanyak dari ketiga kultur $\mathrm{BAL}$, yaitu sebanyak $1,5 \times 10^{7} \mathrm{cfu} / \mathrm{ml}$. Kultur Lactobacillus sp. galur SCG 1221 dan galur SCG 1223 memiliki jumlah koloni yang hampir sama banyaknya, yaitu berturut-turut sebanyak $5,6 \times 10^{6} \mathrm{cfu} / \mathrm{ml}$ dan $6,7 \times 10^{6}$ cfu/ml. Tabel 2 menunjukkan bahwa kultur E. coli yang berumur 24 jam memiliki populasi sebanyak $11,6 \times 10^{12} \mathrm{cfu} / \mathrm{ml}$, sedangkan kultur $S$. aureus yang berumur 24 jam memiliki populasi sebanyak 6,6 × $10^{13} \mathrm{cfu} / \mathrm{ml}$.

Hasil penghitungan populasi semua kultur bakteri menunjukkan bahwa kultur bakteri produsen memiliki populasi yang lebih rendah jika dibandingkan dengan kultur bakteri indikator. Hal tersebut disebabkan kultur induk BAL yang digunakan merupakan hasil peremajaan dari kultur cair yang telah disimpan cukup lama pada suhu $4^{\circ} \mathrm{C}$ dan bukan merupakan hasil peremajaan dari isolat segar, sedangkan kultur bakteri indikator yang digunakan merupakan hasil peremajaan dari kultur yang diawetkan dalam manik-manik. Oleh karena itu, diperlukan waktu lebih lama untuk pengkondisian dan peremajaan kultur
BAL agar didapatkan kultur dengan populasi lebih tinggi. Selain itu, tahap penghitungan jumlah populasi kultur membutuhkan waktu inkubasi lebih dari 24 jam, di mana waktu tersebut merupakan fase kematian bagi kultur BAL. Pada fase kematian, kultur BAL mengalami penurunan jumlah populasi (Januarsyah, 2007). Namun demikian, tidak ada standar minimal jumlah populasi kultur produsen yang dibutuhkan untuk memproduksi bakteriosin.

\section{Produksi dan pengujian ekstrak kasar bakteriosin}

Produksi bakteriosin dilakukan setelah jam ke sembilan inkubasi. Hal ini dilakukan karena pada jam ke sembilan hingga ke sepuluh merupakan akhir fase logaritmik hingga awal fase stasioner (Januarsyah, 2007). Bakteriosin umumnya diproduksi secara optimal oleh bakteri asam laktat pada akhir fase logaritmik hingga awal fase stasioner (Jimenez-Diaz, 1993 cit. Januarsyah, 2007). Ekstrak kasar bakteriosin pada penelitian ini diproduksi dengan menerapkan prinsip metode adsorbsidesorbsi (Yang et al., 1992 cit. Usmiati dan Rahayu, 2011). Prinsipnya adalah pada $\mathrm{pH}$ sekitar netral senyawa pre-bakteriosin akan menempel pada permukaan sel bakteri produser (atau disebut sebagai proses adsorbsi), kemudian pada $\mathrm{pH}$ rendah akan terjadi pelepasan senyawa bakteriosin dari sel bakteri produsen ke lingkungannya (atau disebut sebagai proses desorbsi).

Produksi bakteriosin diawali dengan pengaturan $\mathrm{pH}$ netral $(7,00)$ pada kultur kerja untuk proses adsorbsi, kemudian dilakukan pemanasan 15 menit pada suhu $80^{\circ} \mathrm{C}$ dan $100^{\circ} \mathrm{C}$. Hal ini bertujuan untuk mematikan sel

Tabel 1. Populasi kultur bakteri produsen bakteriosin (population of bacteria culture produce bacteria)

\begin{tabular}{cc}
\hline \hline Bakteri (bacteria) & Jumlah koloni (cfu/ml) (colony number (cfu/ml)) \\
\hline Lactobacillus sp. galur SCG 1211 & $1,5 \times 10^{7}$ \\
Lactobacillus sp. galur SCG 1221 & $5,6 \times 10^{6}$ \\
Lactobacillus sp. galur SCG 1223 & $6,7 \times 10^{6}$ \\
\hline
\end{tabular}

Tabel 2. Populasi kultur bakteri indikator (population of indicator bacteria)

\begin{tabular}{|c|c|}
\hline Bakteri (bacteria) & "Jumlah koloni (cfu/ml) (colony number (cfu/ml)) \\
\hline E. coli & $11,6 \times 10^{12}$ \\
\hline S. aureus & $6,6 \times 10^{13}$ \\
\hline
\end{tabular}


produsen agar tidak terus berkembang selama proses ekstraksi bakteriosin. Prosesproses selanjutnya dilakukan pada suhu $4^{\circ} \mathrm{C}$. Sentrifugasi dilakukan untuk memisahkan antara supernatan dengan massa sel bakteri produsen. Supernatan yang dihasilkan merupakan ekstrak bakteriosin. $\mathrm{pH}$ supernatan kemudian diatur menjadi $\mathrm{pH}$ rendah $(4,00)$ untuk proses desorbsi. Selanjutnya disentrifugasi kembali dan supernatan disaring menggunakan filter millipore 0,20 $\mu \mathrm{m}$ dan didapatkan supernatan bakteriosin bebas sel atau disebut juga sebagai ekstrak kasar bakteriosin. Ketiga jenis sampel ekstrak bakteriosin yang dihasilkan tidak terlihat perbedaannya jika dilihat secara visual. Ekstrak kasar bakteriosin yang dihasilkan berwarna kuning jernih, yang berasal dari warna media MRSB yang digunakan untuk produksi ekstrak kasar bakteriosin.

Ketiga ekstrak kasar bakteriosin diuji untuk menghambat bakteri $E$. coli dan $S$. aureus. Pengujian aktivitas penghambatan dilakukan dengan metode difusi sumur agar. Masing-masing ekstrak kasar bakteriosin diuji secara duplo sebanyak tiga kali ulangan. Aktivitas penghambatan dapat terlihat dari zona bening yang muncul di sekitar sumur agar setelah diinkubasi. Hasil pengujian aktivitas penghambatan ekstrak kasar bakteriosin disajikan pada Tabel 3 dalam bentuk hasil pengukuran diameter zona bening $(\mathrm{mm})$.

Secara umum, ketiga jenis sampel ekstrak kasar menghasilkan rerata zona bening atau zona hambat dengan diameter $9,0 \pm 0,0$ hingga $10,0 \pm 0,0 \mathrm{~mm}$. Sampel ekstrak kasar bakteriosin dari galur SCG 1211 menghasilkan zona hambat dengan diameter 9,5 $\pm 0,0$ hingga 10,0 $\pm 0,0 \mathrm{~mm}$. Sampel ekstrak kasar bakteriosin dari galur SCG 1221 menghasilkan zona hambat dengan diameter $9,0 \pm 0,0$ hingga $9,5 \pm 0,0 \mathrm{~mm}$. Sedangkan sampel ekstrak kasar bakteriosin dari galur SCG 1223, zona hambat yang dihasilkan memiliki diameter 9,0 $\pm 0,0$ hingga 9,5 $\pm 0,0$ $\mathrm{mm}$. Terlihat bahwa ekstrak kasar bakteriosin dari galur SCG 1211 menghasilkan zona hambat dengan diameter yang relatif lebih besar.

Ponce et al. (2007) menyatakan jika sampel yang diujikan menunjukkan adanya zona bening berdiameter lebih besar dari 6 $\mathrm{mm}$ di sekeliling sumur maka dapat dikatakan sampel tersebut positif menghambat bakteri indikator. Tidak terdapat ketentuan khusus diameter zona hambat atau aktivitas hambat $(\mathrm{AU} / \mathrm{ml})$ minimal yang disyaratkan untuk bakteriosin agar dapat dikatakan sebagai agen biopreservatif (Usmiati dan Rahayu, 2011).

Pada luas zona hambat dapat diketahui aktivitas penghambatan ekstrak kasar bakteriosin. Semakin besar zona hambat yang dihasilkan maka semakin besar pula aktivitas penghambatan sampel ekstrak bakteriosin. Aktivitas ekstrak kasar bakteriosin (AU/ml) dalam menghambat E. coli disajikan pada Tabel 4 dan aktivitas ekstrak kasar bakteriosin (AU/ml) dalam menghambat $S$. aureus disajikan pada Tabel 5 .

Secara keseluruhan, ekstrak kasar bakteriosin yang dihasilkan memiliki aktivitas untuk menghambat bakteri $E$. Coli sebesar

Tabel 3. Rerata zona bening pengujian daya hambat bakteriosin (the mean of a clear zone of inhibition testing bacteriocins)

\begin{tabular}{cccccc}
\hline \hline \multirow{2}{*}{$\begin{array}{c}\text { Galur } \\
\text { furrow) }\end{array}$} & \multicolumn{2}{c}{ Diameter zona bening $(\mathrm{mm})$ (clear zone diameter $(\mathrm{mm}))$} \\
\cline { 2 - 3 } \cline { 5 - 6 } & $\begin{array}{c}\text { Suhu } 80^{\circ} \mathrm{C} \\
\left.\text { (temperature } 80^{\circ} \mathrm{C}\right)\end{array}$ & $\begin{array}{c}\text { Suhu } 100^{\circ} \mathrm{C} \\
\left.\text { (temperature } 80^{\circ} \mathrm{C}\right)\end{array}$ & & $\begin{array}{c}\text { Suhu } 80^{\circ} \mathrm{C} \\
\left(\text { temperature } 80^{\circ} \mathrm{C}\right)\end{array}$ & $\begin{array}{c}\text { Suhu } 100^{\circ} \mathrm{C} \\
\left(\text { temperature } 100^{\circ} \mathrm{C}\right)\end{array}$ \\
\hline SCG 1211 & $9,58 \pm 0,49$ & $9,50 \pm 0,00$ & & $10,0 \pm 0,00$ & $9,83 \pm 0,50$ \\
SCG 1221 & $9,00 \pm 0,00$ & $9,00 \pm 0,00$ & & $9,50 \pm 0,00$ & $9,50 \pm 0,00$ \\
SCG 1223 & $9,00 \pm 0,00$ & $9,00 \pm 0,00$ & & $9,50 \pm 0,00$ & $9,50 \pm 0,00$ \\
\hline
\end{tabular}

Tabel 4. Aktivitas hambat bakteriosin terhadap E. coli (bacteriocin inhibitory activity against $E$. coli)

\begin{tabular}{ccc}
\hline \hline Galur (furrow) & \multicolumn{2}{c}{ Aktivitas hambat $(\mathrm{AU} / \mathrm{ml})($ inhibitory activity $(\mathrm{AU} / \mathrm{ml}))$} \\
\cline { 2 - 3 } & $80^{\circ} \mathrm{C}$ & $100^{\circ} \mathrm{C}$ \\
\hline SCG 1211 & $828,78 \pm 4,93$ & $853,01 \pm 0,00$ \\
SCG 1221 & $707,66 \pm 0,00$ & $707,66 \pm 0,00$ \\
SCG 1223 & $707,66 \pm 0,00$ & $707,66 \pm 0,00$ \\
\hline
\end{tabular}


Tabel 5. Aktivitas hambat bakteriosin terhadap $S$. aureus (bacteriocin inhibitory activity against $S$. aureus)

\begin{tabular}{ccc}
\hline \hline & \multicolumn{2}{c}{ Aktivitas hambat (AU/ml) (inhibitory activity $(\mathrm{AU} / \mathrm{ml}))$} \\
\cline { 2 - 3 } Galur (furrow) & $80^{\circ} \mathrm{C}$ & $100^{\circ} \mathrm{C}$ \\
\hline SCG 1211 & $1033,075 \pm 1,89$ & $955.156 \pm 3,06$ \\
SCG 1221 & $853,01 \pm 0,00$ & $853,01 \pm 0,00$ \\
SCG 1223 & $853,01 \pm 0,00$ & $853,01 \pm 0,00$ \\
\hline
\end{tabular}

$707,66 \pm 0,0$ hingga $853,01 \pm 0,0 \mathrm{AU} / \mathrm{ml}$ dan $S$. aureus sebesar $853,01 \pm 0,0$ hingga $1033,075 \pm 1,89 \mathrm{AU} / \mathrm{ml}$. Artinya, setiap $1 \mathrm{ml}$ ekstrak kasar bakteriosin yang dihasilkan mampu menghambat pertumbuhan $E$. coli seluas $707,66 \pm 0,0 \mathrm{~mm}^{2}$ hingga $853,01 \pm 0,0$ $\mathrm{mm}^{2}$ dan setiap $1 \mathrm{ml}$ ekstrak kasar bakteriosin yang dihasilkan mampu menghambat pertumbuhan $E$. coli seluas $853,01 \pm 0,00 \mathrm{~mm}^{2}$ hingga $1033,075 \pm 1,89 \mathrm{~mm}^{2}$.

Ekstrak kasar bakteriosin dari galur SCG 1211 yang diproduksi pada suhu $80^{\circ} \mathrm{C}$ memiliki rerata aktivitas hambat sebesar $828,78 \pm 4,93 \mathrm{AU} / \mathrm{ml}$ terhadap $E$. coli dan $1033,075 \pm 1,89 \mathrm{AU} / \mathrm{ml}$ terhadap $S$. aureus. Tidak berbeda jauh dengan ekstrak kasar yang diproduksi pada suhu $100^{\circ} \mathrm{C}$, memiliki

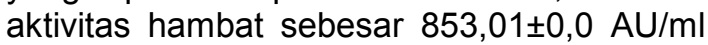
terhadap $E$. coli dan 955,156 $23,06 \mathrm{AU} / \mathrm{ml}$ terhadap $S$. aureus. Ekstrak kasar bakteriosin dari galur SCG 1221 dan SCG 1223 yang diproduksi pada suhu $80^{\circ} \mathrm{C}$ maupun $100^{\circ} \mathrm{C}$, memiliki rerata aktivitas hambat yang sama, yaitu sebesar 707,66 $\pm 0,0 \mathrm{AU} / \mathrm{ml}$ terhadap E. coli dan 853,01 AU/ml terhadap $S$. aureus.

Dilihat dari aktivitas hambatnya, ekstrak kasar bakteriosin dari Lactobacillus sp. galur SCG 1211, SCG 1221, dan SCG 1223 cukup berpotensi sebagai biopreservasi, khususnya jika diaplikasikan pada kemasan produk pangan (kemasan aktif). Ekstrak kasar bakteriosin masih merupakan hasil purifikasi parsial. Jika dipekatkan menjadi bentuk bubuk atau dilakukan tahap purifikasi lebih lanjut, diduga akan menghasilkan bakteriosin dengan aktivitas hambat yang lebih besar lagi. Bubuk bakteriosin dari Lactobacillus sp. galur SCG 1223 memiliki aktivitas hambat yang meningkat hingga $142 \%$ lebih besar dari bentuk ekstrak kasarnya (Nasution, 2009). Lactacin B, bakteriosin yang dihasilkan dari Lactobacillus acidophilus, memiliki aktivitas hambat sebesar $128 \mathrm{AU} / \mathrm{ml}$ saat masih berupa ekstrak kasar dan meningkat menjadi $8192 \mathrm{AU} / \mathrm{ml}$ setelah dilakukan purifikasi lebih lanjut dengan carboxymethyl Sepadhex ${ }^{\mathrm{TM}}$ (Barefoot et al., 1994). Bakteriosin yang dihasilkan dari Bacillus megaterium meng- hasilkan zona bening hingga $11 \mathrm{~mm}$ (atau $1334,5 \mathrm{AU} / \mathrm{ml}$ ) dalam menghambat $E$. coli dan $S$. aureus, serta mampu mereduksi pertumbuhan S. aureus hingga 76\% (Khalil et al., 2009).

Pengaruh faktor galur kultur produsen dan faktor suhu produksi terhadap aktivitas penghambatan ekstrak bakteriosin yang dihasilkan dapat dilihat pada Tabel 6. Hasil analisis menunjukkan bahwa faktor galur kultur produsen berbeda nyata $(P \leq 0,05)$. Hal tersebut dapat diartikan galur kultur produser termasuk faktor yang mempengaruhi aktivitas hambat ekstrak kasar bakteriosin. Sementara itu, faktor suhu produksi tidak berbeda nyata $(P \geq 0,05)$ atau dapat diartikan bahwa suhu produksi bukan merupakan faktor yang mempengaruhi aktivitas hambat ekstrak bakteriosin.

\section{Pengaruh perbedaan galur kultur produser terhadap aktivitas hambat ekstrak kasar bakteriosin}

Ekstrak kasar bakteriosin yang dihasilkan oleh galur kultur yang berbeda memiliki aktivitas hambat yang berbeda pula besarnya. Perbedaan tersebut dapat dilihat pada Tabel 4 yang menunjukkan bahwa ekstrak kasar bakteriosin yang dihasilkan oleh Lactobacillus sp. galur SCG 1221 memiliki rerata aktivitas hambat yang sama besarnya dengan ekstrak kasar bakterison yang dihasilkan oleh galur SCG 1223, yaitu sebesar 707.66, $\pm 0 \mathrm{AU} / \mathrm{ml}$ terhadap $E$. coli dan $853.01 \pm 0,0 \mathrm{AU} / \mathrm{ml}$ terhadap $S$. aureus, sedangkan ekstrak kasar bakteriosin yang dihasilkan oleh galur SCG 1211 memiliki rerata aktivitas hambat paling besar yaitu sebesar $853,01 \pm 0,0 \mathrm{AU} / \mathrm{ml}$ terhadap $E$. coli dan $1033,075 \pm 1,89 \mathrm{AU} / \mathrm{ml}$ terhadap $S$. aureus. Hasil analisis Duncan menunjukkan bahwa galur SCG 1221 dan SCG 1223 berada pada subset yang sama, sedangkan galur SCG 1211 berada pada subset yang berbeda. Hal ini dapat diartikan bahwa galur SCG 1211 berbeda nyata dengan galur SCG 1221 maupun dengan galur SCG 1223, 
sedangkan galur SCG 1221 tidak berbeda nyata dengan galur SCG 1223 .

Pada waktu dan kondisi inkubasi yang sama, kultur Lactobacillus sp. galur SCG 1211 yang digunakan memiliki jumlah koloni paling banyak jika dibandingkan dengan kedua galur lainnya (Tabel 1). Jumlah koloni/biomassa yang lebih banyak akan menghasilkan senyawa bakteriosin yang lebih banyak pula dan aktivitas hambatnyapun akan lebih besar. Hal inilah yang mempengaruhi besarnya aktivitas hambat ketiga ekstrak kasar bakteriosin. Ekstrak kasar bakteriosin yang dihasilkan dari sel produsen dengan banyak koloni akan memiliki aktivitas yang lebih tinggi jika dibandingkan dengan bakteriosin yang dihasilkan dari sel produsen yang lebih sedikit jumlah koloninya, dalam volume yang sama. Hal ini didukung hasil penelitian Usmiati dan Marwati (2007) yang menunjukkan bahwa kultur Lactobacillus sp. galur SCG 1223 yang memiliki populasi sebanyak $4,77 \times 10^{14} \mathrm{cfu} / \mathrm{ml}$ menghasilkan ekstrak kasar bakteriosin dengan aktivitas hambat sebesar 2767,12 AU/ml terhadap E. coli.

\section{Pengaruh perbedaan suhu produksi terhadap aktivitas hambat ekstrak kasar bakteriosin}

Hasil analisis ragam menunjukkan bahwa tidak ada perbedaan aktivitas hambat ekstrak kasar bakteriosin dengan suhu produksi $80^{\circ} \mathrm{C}$ dan $100^{\circ} \mathrm{C}$ pada taraf kepercayaan 95\%. Pada Gambar 1 dapat dilihat bahwa aktivitas hambat ekstrak kasar bakteriosin yang diproduksi dengan suhu $80^{\circ} \mathrm{C}$ memiliki pola yang relatif sama dengan yang diproduksi pada $100^{\circ} \mathrm{C}$. Oleh karena aktivitas hambatnya tidak mengalami perbedaan, maka tahap pemanasan pada produksi ekstrak kasar bakteriosin dapat menggunakan suhu $80^{\circ} \mathrm{C}$ untuk efisiensi energi.

Penelitian Lee et al. (1999) menunjukkan bahwa beberapa bakteriosin yang dihasilkan oleh bakteri asam laktat menunjukkan aktivitas hambat yang stabil pada suhu pemanasan $100^{\circ} \mathrm{C}$ selama 30 menit atau $121^{\circ} \mathrm{C}$ selama 10 menit. Campos et al. (2006) melaporkan bahwa bakteriosin yang dihasilkan oleh $L$. lactis dan E. faecium masih menunjukkan aktivitas hambat yang stabil dalam menghambat $S$. aureus setelah dipanaskan $100^{\circ} \mathrm{C}$ selama 60 menit.
Mekanisme kestabilan bakteriosin terhadap panas terkait dengan struktur molekul bakteriosin yang merupakan peptida sederhana tanpa struktur tersier. Stabilitas panas ini disebabkan oleh adanya daerah yang sangat hidrofobik, ikatan silang yang stabil, dan tingginya kandungan asam amino glisin (De Vuyst dan Vandamme, 1994). Stabil terhadap panas merupakan salah satu karakteristik bakteriosin yang diperlukan sebagai biopreservasi pangan. Umumnya proses produksi pangan menggunakan suhu pemanasan cukup tinggi. Ekstrak kasar bakteriosin dari Lactobacillus sp. galur SCG 1211, SCG 1221, dan SCG 1223 ini menunjukkan kestabilan aktivitas hambat setelah melalui pemanasan $100^{\circ} \mathrm{C}$ selama 15 menit, maka ekstrak kasar bakteriosin tersebut juga berpotensi sebagai biopreservasi pada produk pangan yang menggunakan proses pemanasan.

\section{Perbedaan penghambatan ekstrak kasar bakteriosin terhadap Escherichia coli dan Staphylococcus aureus}

Pola diagram batang pada Gambar 2 menunjukkan bahwa ekstrak kasar bakteriosin yang dihasilkan ketiga jenis galur yang berbeda memiliki aktivitas yang lebih tinggi dalam menghambat $S$. aureus dibandingkan dengan $E$. coli. Hal tersebut disebabkan adanya perbedaan antara bakteri E. coli dan S. aureus. E. coli merupakan jenis bakteri gram negatif, sedangkan $S$. aureus merupakan jenis bakteri gram positif.

Escherichia coli merupakan mikrobia gram negatif yang berbentuk batang lurus, berukuran $1,1-1,5 \mu \mathrm{m} \times 2,0-6,0 \mu \mathrm{m}$, biasanya tidak berkapsul, tidak membentuk spora, penghuni normal usus, mudah tumbuh pada media pertumbuhan sederhana (Pelczar dan Chan, 2008). Bakteri ini seringkali menyebabkan diare akut. E. coli yang menyebabkan diare akut dapat dikelompokkan menjadi enteropathogenic Escherichia coli (EPEC), enterotoxigenic Escherichia coli (ETEC), enteroinvasive Escherichia coli (EIEC), enterohaemorrhagic Escherichia coli (EHEC), dan entero-aggregative Escherichia coli (EAEC).

Bakteri dari gram negatif lebih sulit dirusak oleh bakteriosin karena memiliki membran luar pada dinding selnya. Membran luar ini berperan sebagai barrier permeabel. Membran ini bertanggung jawab untuk mencegah masuknya molekul seperti antibiotik, 


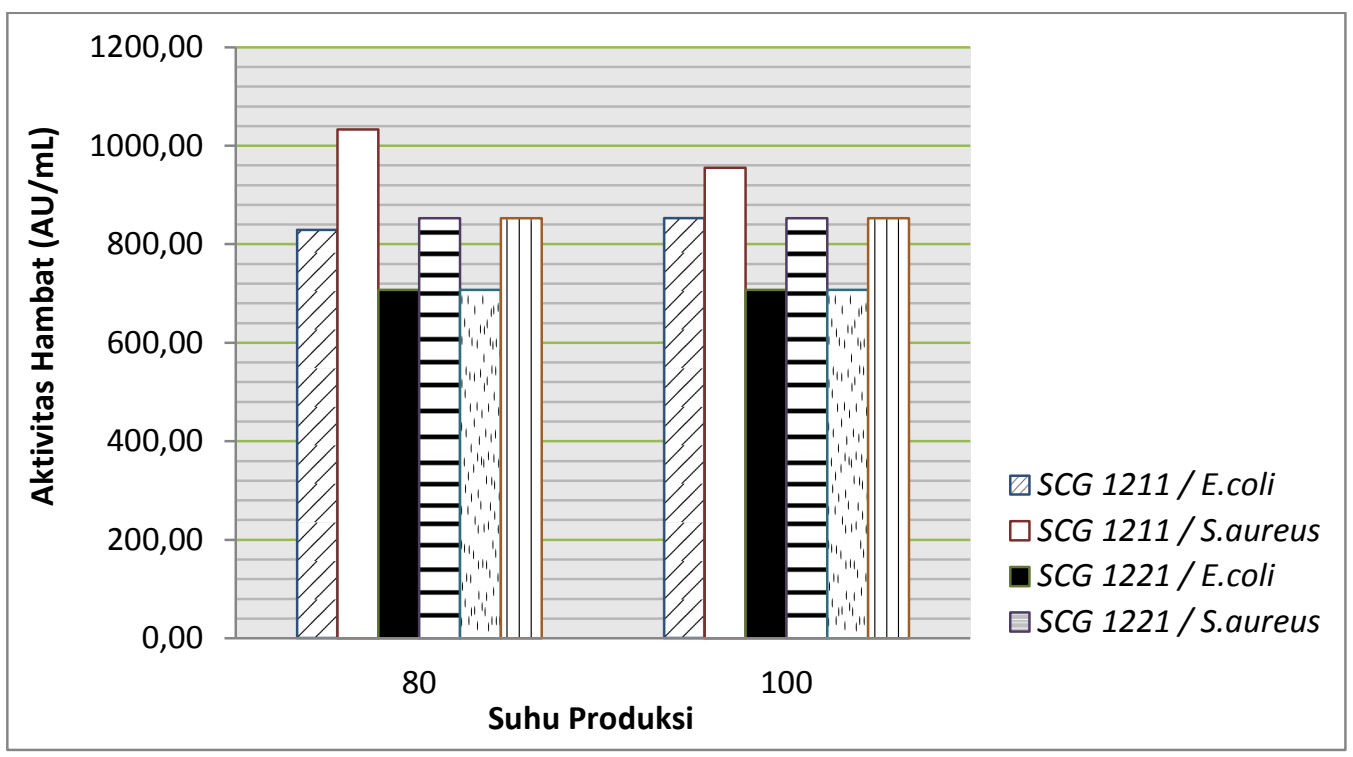

Gambar 1. Diagram batang rerata aktivitas hambat bakteriosin berdasarkan suhu produksi (bar chart bacteriocins mean inhibitory activity based on the temperature of production).

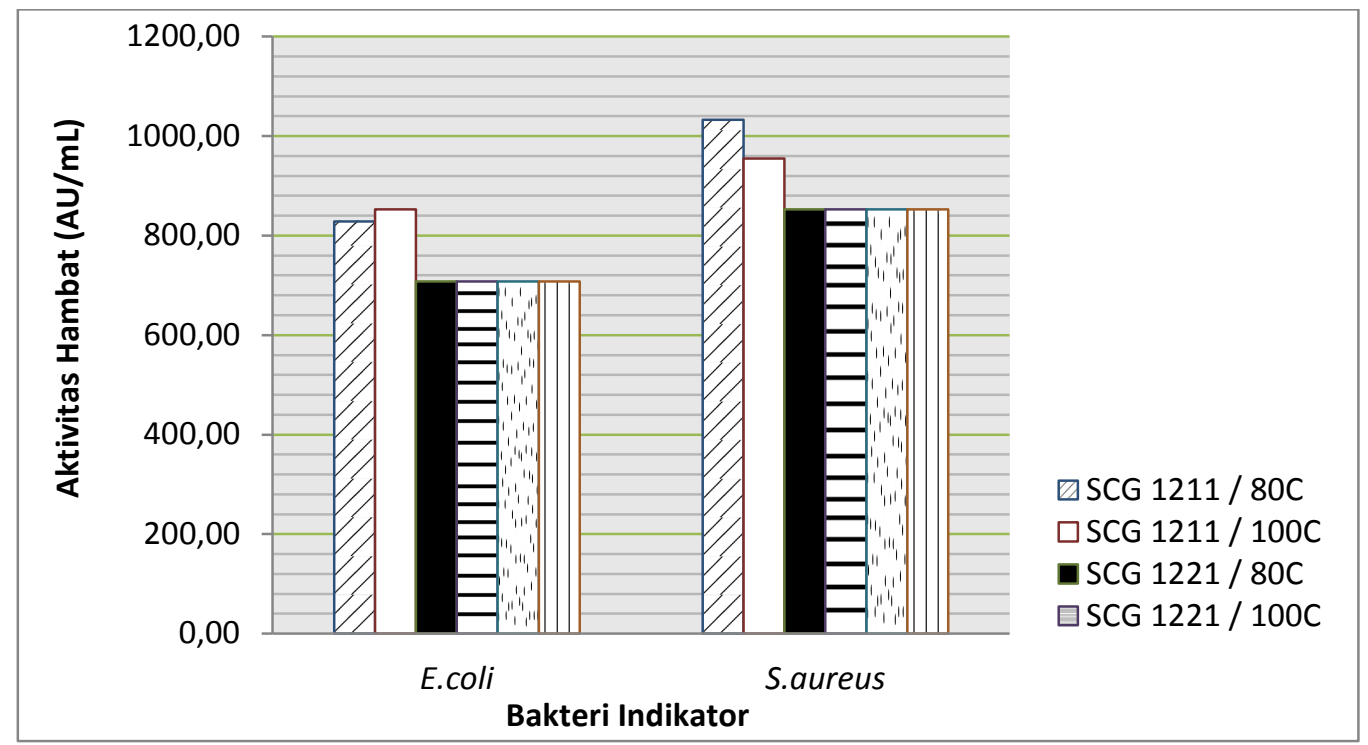

Gambar 2. Diagram batang rerata aktivitas hambat bakteriosin terhadap E.coli dan S. aureus (bar chart bacteriocins mean inhibitory activity against $E$. coli and S. aureus).

deterjen, enzim pencernaan, ke dalam membran sitoplasma (Parada et al., 2007). Aktivitas yang dimiliki oleh ekstrak kasar bakteriosin dari Lactobacillus sp. galur SCG 1211, SCG 1221, dan SCG 1223 dalam menghambat $E$. coli ini diduga karena adanya sisi aktif pada bakteriosin yang bersifat sangat hidrofobik (atau bermuatan negatif), sehingga mampu mengikat $\mathrm{Mg}^{2+}$ pada membran luar E. coli. Terikatnya ion-ion $\mathrm{Mg}^{2+}$ oleh bakteriosin akan menghilangkan integritas lapisan lipopolisakarida dan merusak membran luar dinding sel $E$. coli (Tortora et al., 2007).

S. aureus merupakan mikrobia gram positif yang berbentuk bola (kokus), berdiameter 0,5-1,5 $\mu \mathrm{m}$, dinding selnya mengandung dua komponen utama yaitu peptidoglikan dan asam tekoat yang berkaitan dengannya (Pelczar dan Chan 2008). Penghambatan bakteri gram positif oleh bakteriosin diduga melalui mekanisme berupa 
pembentukan kompleks antara bakteriosin asam lipotekoat yang terdapat pada dinding sel bakteri gram positif, untuk mengawali insersi kerusakan membran sel bakteri tersebut. Asam lipotekoat yang merupakan jenis dari asam tekoat, diduga merupakan reseptor spesifik dan terkait dengan pengikatan senyawa bakteriosin, baik pada bakteri gram positif yang resisten maupun sensitif (Bhunia et al., 1991 cit. Usmiati dan Rahayu, 2011).

Selain itu, bakteriosin umumnya bersifat kationik (karena mengandung residu lisil dan arginil yang berlebih) yang tersusun dari 12-45 asam amino (Moll et al., 1999). Sementara itu, bakteri gram positif mengandung lipid anionik pada membrannya. Lipid atau fosfolipid anionik inilah yang diikat dengan cepat oleh bakteriosin, sehingga menginisiasi terjadinya kerusakan membran sel bakteri (Moll et al., 1999). Kedua hal tersebut menyebabkan bakteri gram positif mudah diserang atau dihambat oleh bakteriosin. Setelah terjadi pengikatan antara membran sel atau sel reseptor bakteri oleh bakteriosin, terjadi pembentukan lubang, kemudian sel bakteri mengalami degradasi DNA seluler, pemotongan spesifik pada $16 \mathrm{~S}$ rDNA, dan penghambatan sintesis peptidoglikan. Pada akhirnya sel akan mengalami lisis atau kematian (De Vuyst dan Vandamme, 1994).

\section{Kesimpulan}

Suhu pemanasan $80^{\circ} \mathrm{C}$ maupun $100^{\circ} \mathrm{C}$, tidak mempengaruhi aktivitas hambat ekstrak kasar bakteriosin yang dihasilkan. Ekstrak kasar bakteriosin memiliki rerata aktivitas hambat paling tinggi dihasilkan oleh Lactobacillus sp. galur SCG 1211, yaitu sebesar $853,01 \pm 0,0 \mathrm{AU} / \mathrm{ml}$ terhadap $E$. coli dan $1033,075 \pm 1,89 \mathrm{AU} / \mathrm{ml}$ terhadap S. aureus. Ekstrak kasar bakteriosin dari Lactobacillus sp. galur SCG 1221 memiliki aktivitas hambat yang sama besar dengan galur SCG 1223, yaitu sebesar $707,66 \pm 0,0$ $\mathrm{AU} / \mathrm{ml}$ terhadap $E$. coli dan $853,01 \pm 0,0 \mathrm{AU} / \mathrm{ml}$ terhadap $S$. aureus. Berdasarkan hasil penelitian, ekstrak kasar bakteriosin yang dihasilkan dari Lactobacillus sp. galur SCG 1211, SCG 1221, dan SCG 1223 dapat dinilai positif menghambat bakteri $E$. coli dan $S$. aureus dengan metode difusi sumur agar.

\section{Ucapan Terima Kasih}

Terimakasih disampaikan kepada $\mathrm{N}$. Hadiyana, alumni Fakultas Teknologi Pertanian, IPB Bogor dan Marman Wahyudi, teknisi Balai Besar Litbang Pascapanen Pertanian, Bogor yang telah membantu penelitian ini hingga selesai.

\section{Daftar Pustaka}

FDA. 2001. Bacteriological Analytical Manual. Food and Drug Administration, Center for Food Safety and Applied Nutrition, Washington, DC.

Barefoot, S. F., C. G. Nettles and Y. R. Chen. 1994. Lactacin B, a bacteriocin produced by Lactobacillus acidophilus. Bacteriocin of Lactic Acid Bacteria: microbiology, genetics, and applications. De Vuyst L. and E. Vandamme (eds). Blackie Academic and Professional, London, pp. 353-376.

Campos, A., O. Rodriguez, P. Calo-Mata, M. Prado and J. Barros-Velazquez. 2006. Preliminary characterization of bacteriocins from Lactococcus lactis, Enterococcus faecium, and Enterococcus mundtii strains isolated from turbot (Psetta maxima). Food Research International 39: 356-364.

De Martinis, E. C. P., M. R. P. Públio, P. R. Santarosa and F. Z. Freitas. 2001. Antilisterial activity of lactic acid bacteria isolated from vacuumpackaged Brazilian meat and meat products. Braz. J. Microbiol. 32: 32-37.

De Vuyst, L. and E. Vandamme. 1994. Antimicrobial potential of lactic acid bacteria. Bacteriocin of Lactic Acid Bacteria: microbiology, genetics, and applications. De Vuyst L. and E. Vandamme (eds). Blackie Academic and Professional, London, pp. 91-142.

De Vuyst, L. and F. Leroy 2007. Bacteriocins from lactic acid bacteria: production, purification, and food applications. J. Molecular Microbiol. Biotechnol. 13: 194-199.

Delgado, A., D. Brito, P. Fevereiro, R. Tenreiro, C. Peres. 2005. Bioactivity quantification of crude bacteriocin solutions. J. Microbiological Methods 62: 121-124. 
Januarsyah, T. 2007. Kajian aktivitas hambat bakteriosin dari bakteri asam laktat galur SCG 1223. Skripsi Institut Pertanian Bogor, Bogor.

Khalil, R., Y. Elbahloul, F. Djadouni and S. Omar 2009. Isolation and partial characterization of a bacteriocin produced by a newly isolated Bacillus megaterium 19 strain. Pakistan J. Nutrition 8: 242-250.

Klaenhammer, T. R. 1993. Genetics of bacteriocins produced by lactic acid bacteria. FEMS Microbiol. Rev. 12: 3985.

Lee, H. J., Y. J. Joo, C. S. Park, S. H. Kim, I. K. Hwang, J. S. Ahn and T. I. Mheen. 1999. Purification and characterization of a bacteriocin produced by Lactococcus lactis subsp. lactis $\mathrm{H}-559$ isolated from kimchi. J. Biosci. Bioengineering 88: 153-159.

Moll, G. N., W. N. Konings and A. J. M. Driessen. $1999 . \quad$ Bacteriocins: mechanism of membrane insertion and pore formation. J. Antonie van Leeuwenhoek 76: 185-198.

Nasution, S. R. 2009. Kajian aktivitas hambat pertumbuhan bakteri patogen oleh serbuk bakteriosin yang dihasilkan bakteri asam laktat galur SCG 1223. Skripsi Institut Pertanian Bogor, Bogor.

Nurhasanah. 2004. Produksi bakteriosin pada berbagai tingkat aerasi dan uji kestabilan bakteriosin dari bakteri asam laktat Galur M6-15. Skripsi Institut Pertanian Bogor, Bogor.

Parada, J. L., C. R. Caron, A. B. P. Medeiros and C. R. Soccol. 2007. Bacteriocins from lactic acid bacteria: purification, properties, and use as biopreservatives. Brazilian Archives of Biology Technol. 50: 521-542.
Pelczar, M. J. Jr. and E. C. S. Chan. 2008. Dasar-Dasar Mikrobiologi II. Penerjemah: Hadioetomo R. S, Imas T, Tjitrosomo S. S, Angka S. L. Terjemahan dari: Elements of Microbiology, UI Press, Jakarta.

Ponce, A. G, M. R. Moreira, C. E. Del Valle and S. I. Roura. 2007. Preliminary characterization of bacteriocin-like substances from lactic acid bacteria isolated from organis leafy vegetables. J. LWT 41: 432-441.

Tagg, J. R. and A. R. McGiven. 1971. Assay System for Bacteriocins. J. Appl. Microbiol. 21: 943.

Todorov, S. D. and L. M. T. Dicks. 2004. Influence of growth conditions on the production of a bacteriocin by Lactobacillus lactis subsp. lactis ST34BR, a strain isolated from barley beer. J. Basic Microbiol. 44: 305-316.

Tortora, G. J., B. R. Funke and C. L. Case 2007. Microbiology: an Introduction, $9^{\text {th }}$ edn. Pearson Benjamin Cummings. San Francisco, p.88.

Usmiati, S. dan T. Marwati 2007. Seleksi dan optimasi proses produksi bakteriosin dari Lactobacillus sp. Jurnal Pascapanen 4: 27-37.

Usmiati, S. dan W. P. Rahayu. 2011. Aktivitas hambat bubuk ekstrak bakteriosin dari Lactobacillus sp. galur SCG 1223. Prosiding Seminar Nasional Teknologi Peternakan dan Veteriner, Puslitbangnak. 